\title{
Treating vaginitis with probiotics in non-pregnant females: A systematic review and meta-analysis
}

\author{
HUEY-SHENG JENG $^{1,2}$, TSONG-RONG YAN ${ }^{1}$ and JING-YI CHEN ${ }^{3}$ \\ ${ }^{1}$ Department of Chemical Engineering and Biotechnology, Institute of Chemical Engineering and Biotechnology, \\ Tatung University, Taipei $10452 ;{ }^{2}$ Department of Urology, Zhong-Xing Branch, Taipei City Hospital, Taipei 10341; \\ ${ }^{3}$ School of Medicine for International Students, College of Medicine, I-Shou University, Kaohsiung 82445, Taiwan, R.O.C.
}

Received November 11, 2019; Accepted March 24, 2020

DOI: $10.3892 /$ etm.2020.9090

\begin{abstract}
Vaginitis, also known as vulvovaginitis, is an inflammation of the vagina and vulva and a common disease in females. It is thought to be caused by vaginal dysbiosis and improved by probiotics. Bacterial vaginosis (BV) and vulvovaginal candidiasis (VVC) are the major types of vaginal infections. The present systematic review and meta-analysis aimed to clarify the efficacy of probiotics in the treatment of common vaginal infections in non-pregnant females. Literature on randomized controlled trials and two-armed prospective studies on any intervention with probiotics published until December 24th, 2018 was searched in the PubMed, Cochrane and EMBASE databases. The outcomes of interest were recurrence rate, cure rate, remission rate and normal vaginal flora restoration. Finally, a total of 30 studies on bacterial vaginosis (BV) and/or VVC were included and stratified into 3 study types based on treatment design as follows: Type I, antibiotic/probiotics vs. antibiotics/antifungals (22 studies); Type II, probiotics vs. placebo (5 studies); Type III, probiotics vs. antibiotics (3 studies). The type I studies comprised 1,788 non-pregnant females and had the highest inter-study comparability in post-treatment follow-up design and meta-analysis outcome data. Probiotics interventions were significantly associated with a lower recurrence rate of vaginitis [pooled odds ratio $(\mathrm{OR})=0.27,95 \% \mathrm{CI}$ : $0.18-0.41$, $\mathrm{P}<0.001]$ and higher cure/remission rate (pooled $\mathrm{OR}=2.28$, 95\% CI: 1.20-4.32, $\mathrm{P}=0.011)$. However, a significant increase in normal vaginal flora after probiotic treatment was observed
\end{abstract}

Correspondence to: Professor Tsong-Rong Yan, Department of Chemical Engineering and Biotechnology, Institute of Chemical Engineering and Biotechnology, Tatung University, Number 40, Section 3, Zhongshan North Road, Taipei 10452, Taiwan, R.O.C. E-mail: tryan@gm.ttu.edu.tw

Abbreviations: $\mathrm{BV}$, bacterial vaginosis; VVC, vulvovaginal candidiasis; UTI, urinary tract infection

Key words: probiotics, Lactobacillus, vaginitis, bacterial vaginosis, vulvovaginal candidiasis, meta-analysis only in BV (pooled OR=4.55, 95\% CI: 1.44-14.35, P=0.01). In addition, supportive but heterogeneous results were obtained from the 6-month follow-up data of Type-I studies, different infection types and supplementary analysis of Type-II studies. In conclusion, probiotics have a significant short-term effect in the treatment of common vaginal infections in non-pregnant females. In order to evaluate the long-term effects of probiotics in common vaginal infections, it is worthwhile to perform higher-quality clinical trials in the future.

\section{Introduction}

Vaginal infections of bacterial vaginosis (BV) and vulvovaginal candidiasis (VVC) are common in females, accounting for almost $80 \%$ of all cases of vaginitis also known as vulvovaginitis, is an inflammation of the vagina and vulva. Symptoms may include itching, burning, pain, discharge and a bad odor $(1,2)$. While BV is generally regarded as a mild disease, it has been indicated to be associated with the occurrence of endometritis and pelvic inflammatory disease in females without clinical symptoms of BV and may lead to spontaneous abortion, premature rupture of the membranes, and premature delivery during pregnancy $(2,3)$. VVC results from overgrowth of one or more types of yeast organism (e.g., Candida albicans) that normally inhabit the vaginal mucosa in small numbers, and symptoms include external dysuria, pruritus, redness and flocculant vaginal discharge $(2,4)$. In most cases, standard treatments with antibiotics or anti-fungals are effective for BV and VVC. However, the use of antibiotics may cause physiological and non-physiological changes in patients, and interfere with the balance of the normal vaginal microbiota. Thus, the common side-effects of antibiotic treatment are characterized by reduction or depletion of the Lactobacillus species and the excessive growth of Candida species. In addition, excessive use of antibiotics frequently causes the emergence of resistant strains.

Probiotics are defined as 'live microorganisms when administered in adequate amounts confer a health benefit to the host' (5). Over the past 2 decades, accumulating evidence has indicated that the intestinal and urogenital microflora has a central role in maintaining the health of human beings (5). In addition, the use of beneficial bacteria to improve dysbiosis by replacing pathogenic bacteria or augmenting normal microflora 
has been gradually accepted and proven useful in conditions including necrotizing enterocolitis and antibiotic-resistant infections (5). The intestinal, vaginal and urethral microflora have an important role in maintaining health and preventing gynecologic infections in females, and the use of probiotics has been extended to the treatment of refractory cases of female urogenital infections (5).

The use of probiotics has been examined in a number of studies over the past 2 decades as a method of treating and reducing the risk and recurrence rate of gynecologic infections in females, particularly in whom standard treatments are not effective. Probiotics may protect the vagina from pathogen colonization through a number of mechanisms, including blocking potential sites of attachment, production of microbiocidal substances, e.g. hydrogen peroxide, maintenance of a low $\mathrm{pH}$ and induction of anti-inflammatory cytokine responses in epithelial cells (3-5). The most common probiotics used in female patients are of the Lactobacillus species (3-5).

While numerous clinical trials have been performed to determine the effectiveness of probiotics for the treatment of vaginal infections, the results have generally been inconsistent, with certain studies suggesting an excellent response and other indicating no effect. Meta-analyses have also provided inconsistent results. A meta-analysis by Huang et al (3) from 2014 indicated that probiotic supplementation improves the cure rate for BV. Other previously published systematic reviews have suggested that the use of probiotics remains controversial in preventing $\mathrm{BV}$ and $\mathrm{VVC}$ in adult females due to evidence limitations $(4,6,7)$. Potential bias on the benefits of probiotics cannot be ruled out, as the majority of evidence came from small-scale studies, heterogeneous populations, different lengths of follow-up and inhomogeneous treatment designs among the study. Similar views were also expressed by a recently published systemic review by Hanson et al (4) from 2016 with a focus on urogenital infections in non-pregnant females, highlighting the requirement of carefully-planned study stratification upon meta-analysis.

The purpose of the present study was to perform a meta-analysis of randomized controlled trials (RCTs) and two-armed prospective studies identified by a thorough systematic review and meta-analysis of adequately-selected literature to determine the effect of probiotics for the treatment of common vaginal infections in non-pregnant adult females.

\section{Materials and methods}

Literature search strategy and inclusion criteria. The present systematic review and meta-analysis was performed in accordance with the Preferred Reporting Items for Systematic Reviews and Meta-Analyses guidelines (8). On December 24th, 2018, the Pubmed, Cochrane and EMBASE databases were searched for all studies published previously using the following key words: 'Probiotics', 'Lactobacillus', 'urogenital infections', 'bacterial vaginosis', 'vulvovaginitis', 'vaginitis' and 'candidiasis'. The search strategy was (probiotics or Lactobacillus) and (vaginosis or vulvovaginal candidiasis or vaginitis or vulvovaginitis or urogenital infections). Articles of interest were also hand-searched for potentially relevant studies. Searches were performed by 2 independent reviewers (HSJ and JYC) and any disagreements were resolved by a third reviewer (TRY). Inclusion criteria for the analysis were as follows: i) RCTs and two-armed prospective studies; ii) studies including females with a current or history of gynecologic infections of BV and/or VCC; iii) studies that examined probiotic treatment vs. non-probiotics treatment (control) with or without antibiotics; iv) studies that provided quantitative data of the outcomes of interest; and v) full-text articles published in English or Chinese. Exclusion criteria were as follows: i) Retrospective studies, cohort studies, case series, letters, comments, editorials, case reports, proceedings, personal communications and one-arm studies; ii) studies on pediatric patients, pregnant females or males; iii) studies on healthy females with/without a history of recurrent urogenital infections. Studies designed to examine Lactobacillus treatment in combination with estriol, probiotic agents containing an unknown number of Lactobacilli or a mixture of multiple types of non-Lactobacillus bacteria were also excluded.

Data extraction. The following information/data was extracted from studies that met the inclusion criteria: Name of the first author, year of publication, study design, number of participants in each group, participants' age, type of infection, type of interventions, probiotic agents, probiotic administration, length of follow-up period and major outcomes (recurrence rate, cure/remission rate and/or the rate of restoring normal vaginal flora).

Quality assessment. The quality of the RCTs included was assessed using the Cochrane 'assessing risk of bias' table, which consists of 6 domains (random sequence generation, allocation concealment, blinding of patients and personnel, blinding of outcome assessment, incomplete outcome data and selective reporting risk) (9). The quality of non-RCTs was assessed using a Cochrane risk of bias assessment tool for non-randomized studies of interventions (ACROBAT-NRSI) (10). This tool assesses 7 sources of bias associated with confounding, selection of participants, measurement of interventions, departures from intended interventions (10), missing data, measurement of outcomes and selection of the reported result.

Statistical analysis. Outcome measures for the meta-analysis were recurrence rate, cure and/or remission rate and restoration rate of normal flora. The odds ratios (ORs) with $95 \%$ CIs were calculated for each individual study and for all the studies combined. ORs of $<1$ for recurrence and ORs of $>1$ for cure and/or remission rate and normal flora restoration rate indicated that the probiotic group was favored. By contrast, ORs of $>1$ for recurrence and ORs of $<1$ for cure and/or remission rate and normal flora restoration rate indicated the control group was favored. $\mathrm{OR}=1$ indicated that the probiotic and control groups had comparable outcomes. A $\chi^{2}$-based test of homogeneity was performed and the inconsistency index $\left(\mathrm{I}^{2}\right)$ and Q-statistics were determined. A random effect model (DerSimonian-Laird method) was considered for the meta-analysis if either the $\mathrm{Q}$ statistic of $\mathrm{P}<0.10$ or $\mathrm{I}^{2}$ value of $>50 \%$ were derived; otherwise, a fixed effect model (Mantel-Haenszel method) was considered for the meta-analysis (11). Heterogeneity determined using the $\mathrm{I}^{2}$ statistic was defined as follows: 0-24\%, no heterogeneity; 25-49\%, moderate heterogeneity; $50-74 \%$, high heterogeneity; 
and $75-100 \%$, extreme heterogeneity. When the number of studies included in a meta-analysis is small, heterogeneity tests have low statistical power (12) and in this situation, a random-effects model of analysis is used (13). The National Research Council recommends the use of random-effects approaches for meta-analysis and the exploration of sources of variation in study results (14). Pooled effects were calculated and a 2 -sided $\mathrm{P}<0.05$ was considered to indicate statistical significance. Sensitivity analysis was performed using the leave-one-out approach to test the validity and robustness of the major results (12). All analyses were performed using Comprehensive Meta-Analysis statistical software, version 2.0 (Biostat).

\section{Results}

Literature search. A flow diagram of the study selection process is provided in Fig. 1. A total of 771 articles were identified by database- and hand-searching with duplicates removed. After screening by title and abstract, 682 articles were excluded based on inclusion and exclusion criteria. The full text of the remaining 89 articles was reviewed and 59 were further excluded for reasons presented in Fig. 1. The remaining 30 articles were included in the qualitative synthesis, including 20 studies for BV alone or with other pathogens (15-34), 10 studies for VVC alone (31,35-43) and 1 study for BV/VVC (44).

Characteristics of the reviewed studies. Studies were categorized into three types based on treatment design (Table I): Type I, antibiotics plus Lactobacillus (probiotic) vs. antibiotic with or without placebo (control; $n=22)(15,17,18,20,22-26,29,31,32,35$ 41); type II, Lactobacillus (probiotic) vs. placebo (control; no antibiotics; n=5) $(19,21,27,33,34)$; and type III, Lactobacillus (probiotic) vs. antibiotic (control; $n=3)(16,28,30)$. A summary of the patients' characteristics and interventions for the treatment of BV and/or VVC is provided in Table I. The age range of the female patients included in the analysis was between 18 to 50 years. Table II presents a summary of the outcomes of the studies included. Table III provides a summary of the type of probiotic and the route and dose of administration for the treatment of vaginitis. Probiotic species included L. rhamnosus BMX54, L. fermentum, L. plantarum, L. gasseri, L. plantarum, L. acidophilus, L. brevis CD2, L. salivarius subsp. Salicinius, L. delbrueckii subsp. lactis, L. reuteri, P. acidilactici, L. casei rhamnosus, L. reuteris, B. bifidum, B. longum, L. crispatus and Lactobacillus $G G$ either alone or in various combinations depending on the infection being treated. The route of administration included oral capsule, vaginal tablet and vaginal capsule (Table III).

Meta-analysis. The detailed treatment outcomes of all studies reviewed are summarized in Table II. The majority of studies adopted a type I treatment design for BV and/or VVC infections and those with 1- and/or 6-months follow-up data were included in the meta-analysis. These comprised of a total of 21 articles (10 articles on BV, 9 studies on VVC and 2 on BV/VVC) $(15,17,18,20,22-26,29,31,32,35-41)$. The total number of patients evaluated in the 21 type I studies was 1,788 (probiotic test group, $n=910$; control group, $n=878$ ). These type I studies were the major focus of the present meta-analysis,

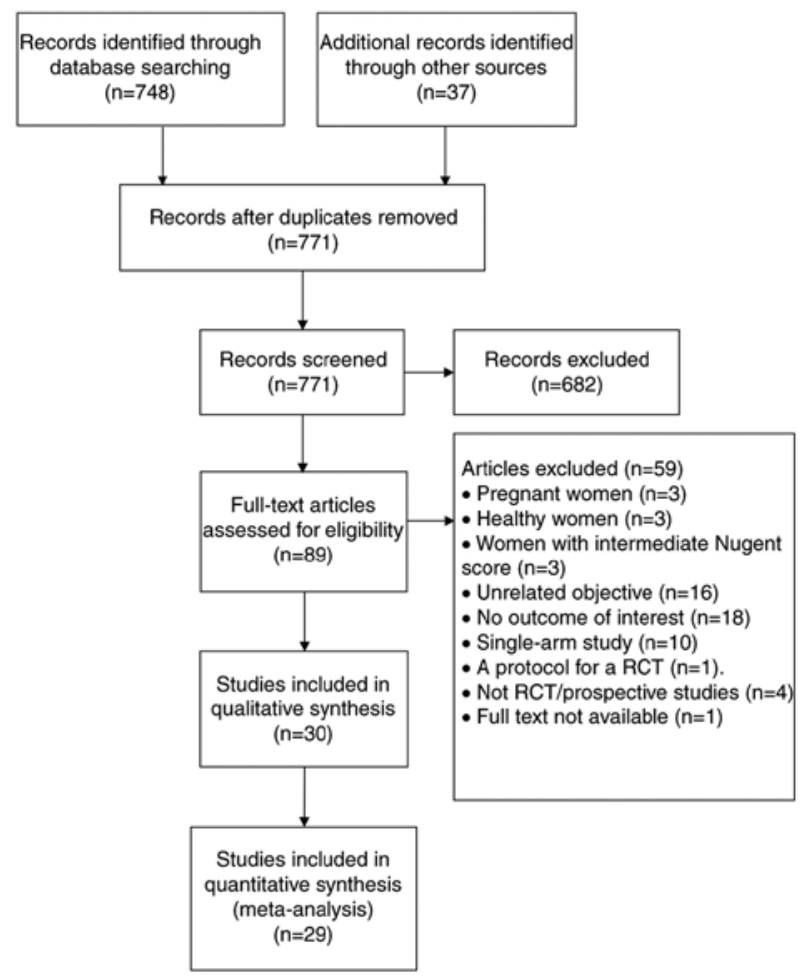

Figure 1. Flow diagram of study selection in accordance with Preferred Reporting Items for Systematic Reviews and Meta-Analyses.

while type II and III studies were analyzed separately for supplementation.

With respect to recurrence at 1 month after treatment, 9 studies [2 on BV alone $(15,26), 5$ on VVC alone $(37,38,40,42,43)$ and 2 on $\operatorname{BV/VVC~}(31,44)]$ with complete quantitative data were included in the present meta-analysis. A total of 1,220 patients were evaluated (probiotic test group, $n=631$; control group, $n=589$ ). There was no heterogeneity present among all 9 studies or those on either BV or VVC (total: $\mathrm{Q}=11.82, \mathrm{I}^{2}=24 \%$; $\mathrm{BV}$ : $\mathrm{Q}=2.14$, $\mathrm{I}^{2}=7 \%$; VVC: $\mathrm{Q}=1.86, \mathrm{I}^{2}=0 \%$; Fig. $2 \mathrm{~A}$ ). The analysis indicated that patients in the probiotic group had a significantly lower recurrence rate than those in the control group (pooled $\mathrm{OR}=0.27,95 \%$ CI: 0.18-0.41; Fig. 2A). A favorable outcome associated with the probiotics group was also observed when analyzing BV and VVC individually (BV: Pooled $\mathrm{OR}=0.10$, 95\% CI: 0.04-0.26; VVC: Pooled OR=0.27, 95\% CI: 0.16-0.45; all $\mathrm{P}<0.001$; Fig. 2A). However, there was no significant difference in the recurrence rate between the probiotic and control groups at 6 months after treatment (Fig. 2A).

With respect to cure or remission after treatments, a total of 12 studies were included. These comprised 12 studies with 1-month follow-up results [6 for BV alone $(15,18,23,24,26,29)$, 4 for VVC alone $(37,38,40,42)$ and 2 for BV/VVC $(31,44)]$ and 2 studies $(22,24)$ with 6 -month follow-up for BV alone. In the 12 studies with 1-month follow-up outcomes, 1,643 patients in total were evaluated (probiotic test group, $n=836$; control group, $\mathrm{n}=807$ ). There was moderate to high heterogeneity among the 12 studies with 1-month follow-up (total: $\mathrm{Q}=52.69, \mathrm{I}^{2}=77 \%$; BV: $\mathrm{Q}=47.02, \mathrm{I}^{2}=87 . \%$; VVC: $\mathrm{Q}=5.45, \mathrm{I}^{2}=27 \%$ ), as well as between studies with 6-month follow-up $\left(\mathrm{Q}=1.70, \mathrm{I}^{2}=40 \%\right)$. 


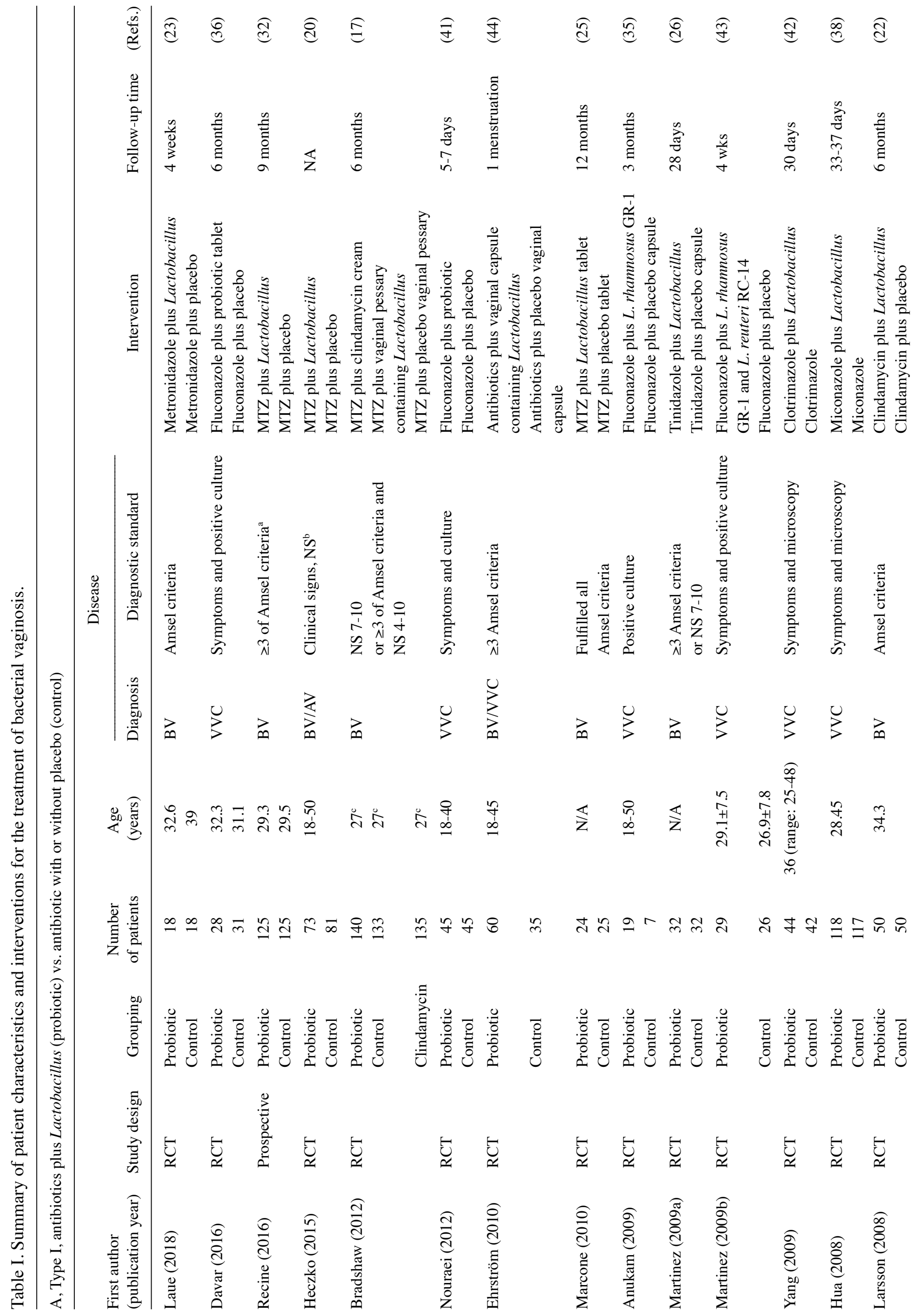




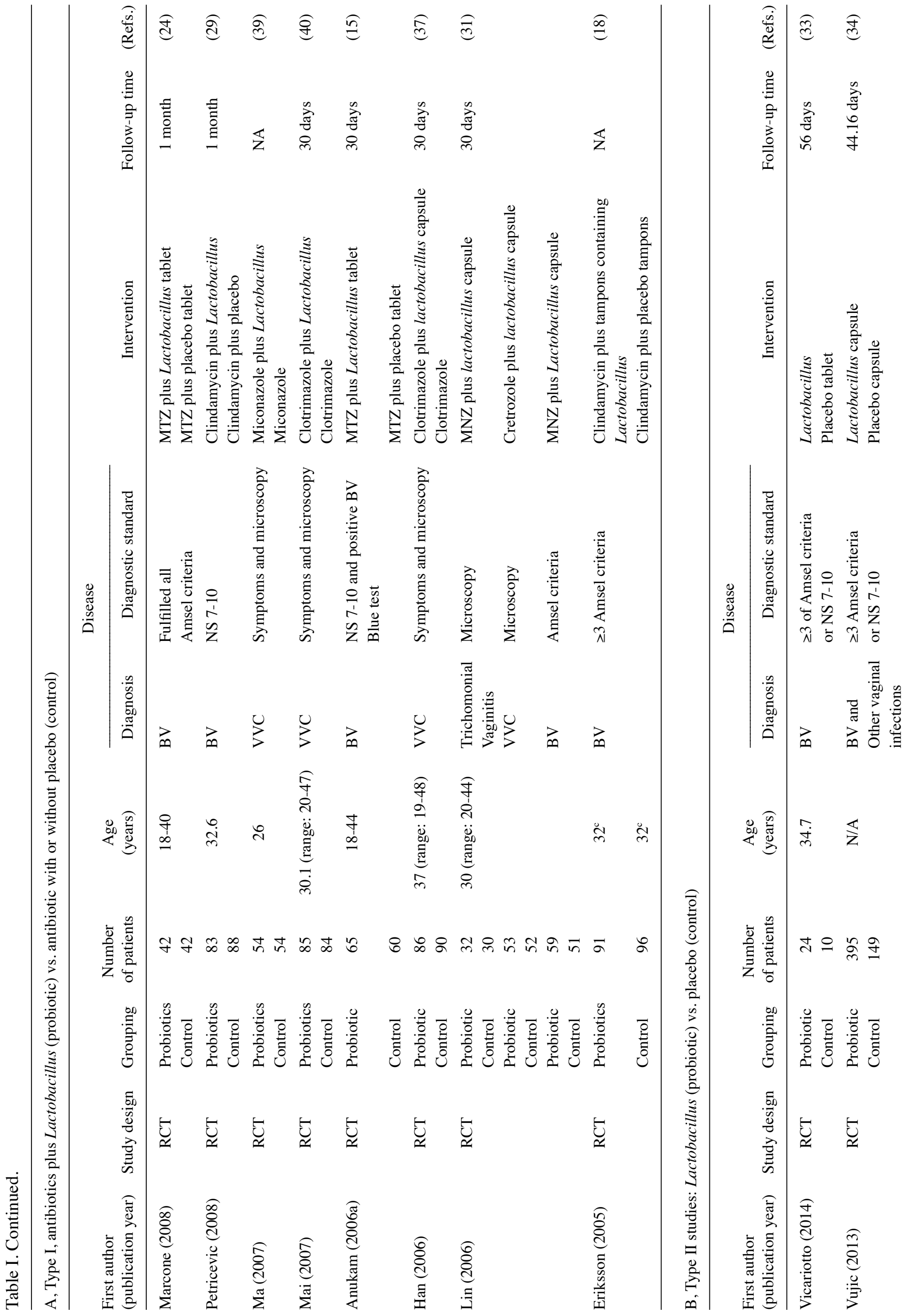




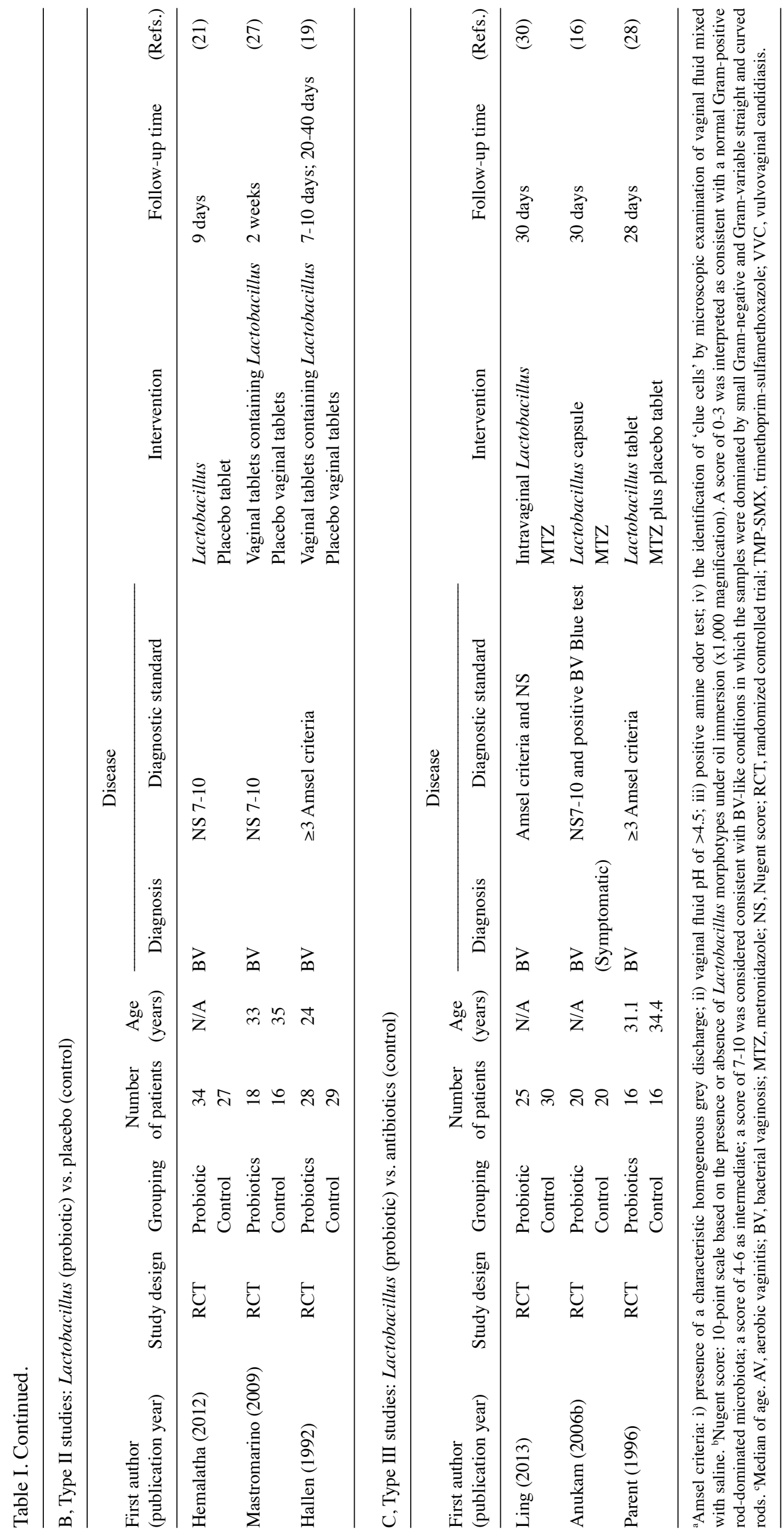


Table II. Summary of the outcomes in the meta-analysis.

\begin{tabular}{|c|c|c|c|c|c|c|c|}
\hline First author (year) & $\begin{array}{l}\text { Disease } \\
\text { type }\end{array}$ & Patients (n) & Intervention & Recurrence & Cure/remission & $\begin{array}{c}\text { Restored } \\
\text { normal flora }\end{array}$ & (Refs.) \\
\hline Laue (2018) & $\mathrm{BV}$ & $\begin{array}{l}18 \\
18\end{array}$ & $\begin{array}{l}\text { Probiotic } \\
\text { Control }\end{array}$ & & $\begin{array}{l}16(100) \\
13(76.5)\end{array}$ & & (23) \\
\hline Davar (2016) & VVC & $\begin{array}{l}28 \\
31\end{array}$ & $\begin{array}{l}\text { Probiotic } \\
\text { Control }\end{array}$ & $\begin{array}{c}2(7.2) \\
11(35.5)\end{array}$ & & & (36) \\
\hline Recine (2016) & $\mathrm{BV}$ & 125 & $\begin{array}{l}\text { Probiotic } \\
\text { Control }\end{array}$ & & & $\begin{array}{c}2 \text { mo: } 113(90.4) \\
6 \text { mo: } 106(74.6) \\
9 \text { mo: } 118(79.7) \\
2 \text { mo: } 99(79.2) \\
6 \text { mo: } 36(25.4) \\
9 \text { mo: } 30(20.3)\end{array}$ & (32) \\
\hline Heczko (2015) & $\mathrm{BV} / \mathrm{AV}$ & $\begin{array}{l}73 \\
81\end{array}$ & $\begin{array}{l}\text { Probiotic } \\
\text { Control }\end{array}$ & $\begin{array}{l}33(45.2) \\
38(47.0)\end{array}$ & & & (20) \\
\hline Bradshaw (2012) & $\mathrm{BV}$ & $\begin{array}{l}140 \\
133 \\
135\end{array}$ & $\begin{array}{l}\text { Clindamycin } \\
\text { Probiotic } \\
\text { Control }\end{array}$ & $\begin{array}{c}42(30) \\
37(27.8) \\
36(26.7)\end{array}$ & & $\begin{array}{l}92(65.7) \\
63(47.4) \\
63(46.7)\end{array}$ & (17) \\
\hline Nouraei (2012) & VVC & $\begin{array}{l}45 \\
45\end{array}$ & $\begin{array}{l}\text { Probiotic } \\
\text { Control }\end{array}$ & & $\begin{array}{l}42(93.3) \\
37(82.2)\end{array}$ & & (41) \\
\hline Ehrström (2010) & $\mathrm{BV} / \mathrm{VVC}$ & 35 & Probiotic & $\begin{array}{l}1 \text { mo: } 13(22.4) \\
2 \text { mo: } 23(38.1) \\
6 \text { mo: } 35(58.4) \\
1 \text { mo: } 10(29.4) \\
2 \text { mo: } 13(38.1) \\
6 \text { mo: } 20(56.6)\end{array}$ & 1 mo: 25 (71) & & (44) \\
\hline Marcone (2010) & $\mathrm{BV}$ & $\begin{array}{l}24 \\
25\end{array}$ & $\begin{array}{l}\text { Probiotic } \\
\text { Control }\end{array}$ & & & $\begin{array}{c}6 \text { mo: } 18(74) \\
12 \text { mo: } 16(69) \\
6 \text { mo: } 24(96) \\
12 \text { mo: } 23(91)\end{array}$ & (25) \\
\hline Anukam (2009) & VVC & $\begin{array}{r}19 \\
7\end{array}$ & $\begin{array}{l}\text { Probiotic } \\
\text { Control }\end{array}$ & & $\begin{array}{c}15(79) \\
3(43)\end{array}$ & & (35) \\
\hline Martinez (2009a) & BV & $\begin{array}{l}32 \\
32\end{array}$ & $\begin{array}{l}\text { Probiotic } \\
\text { Control }\end{array}$ & $\begin{array}{c}4(12.5) \\
15(46.9)\end{array}$ & $\begin{array}{c}28(87.5) \\
16(50)\end{array}$ & $\begin{array}{c}24(75) \\
11(34.4)\end{array}$ & (26) \\
\hline Martinez (2009b) & VVC & $\begin{array}{l}29 \\
26\end{array}$ & $\begin{array}{l}\text { Probiotic } \\
\text { Control }\end{array}$ & $\begin{array}{c}3(10.3) \\
10(38.5)\end{array}$ & & & (43) \\
\hline Yang (2009) & VVC & $\begin{array}{l}44 \\
42\end{array}$ & $\begin{array}{l}\text { Probiotic } \\
\text { Control }\end{array}$ & $\begin{array}{c}3(7.1) \\
7(16.7)\end{array}$ & $\begin{array}{l}42(92.86) \\
38(83.33)\end{array}$ & & (42) \\
\hline Hua (2008) & VVC & $\begin{array}{l}118 \\
117\end{array}$ & $\begin{array}{l}\text { Probiotic } \\
\text { Control }\end{array}$ & $\begin{array}{c}4(4.8) \\
11(13.9)\end{array}$ & $\begin{array}{l}83(70.34) \\
79(67.52)\end{array}$ & & (38) \\
\hline Larsson (2008) & $\mathrm{BV}$ & $\begin{array}{l}50 \\
50\end{array}$ & $\begin{array}{l}\text { Probiotics } \\
\text { Control }\end{array}$ & & $\begin{array}{l}24(64.9) \\
18(46.2)\end{array}$ & & (22) \\
\hline Marcone (2008) & $\mathrm{BV}$ & 42 & Probiotics & & $\begin{array}{l}1 \text { mon: } 22(96) \\
6 \text { mon: } 23(98) \\
1 \text { mon: } 21(91) \\
6 \text { mo: } 17(74)\end{array}$ & $\begin{array}{c}30 \mathrm{~d}: 37(88) \\
90 \mathrm{~d}: 37(88) \\
180 \mathrm{~d}: 35(83) \\
30 \mathrm{~d}: 34(81) \\
90 \mathrm{~d}: 30(71) \\
180 \mathrm{~d}: 28(67)\end{array}$ & (24) \\
\hline Petricevic (2008) & $\mathrm{BV}$ & $\begin{array}{l}83 \\
88\end{array}$ & $\begin{array}{l}\text { Probiotics } \\
\text { Control }\end{array}$ & & $\begin{array}{l}1 \text { mon: } 83(100) \\
1 \text { mon: } 35(39.8)\end{array}$ & $\begin{array}{l}69(83.1) \\
31(35.2)\end{array}$ & (29) \\
\hline Ma (2007) & VVC & $\begin{array}{l}54 \\
54\end{array}$ & $\begin{array}{l}\text { Probiotics } \\
\text { Control }\end{array}$ & & $\begin{array}{l}46(85.2) \\
38(70.4)\end{array}$ & & (39) \\
\hline Mai (2007) & VVC & $\begin{array}{l}85 \\
84\end{array}$ & $\begin{array}{l}\text { Probiotics } \\
\text { Control }\end{array}$ & $\begin{array}{c}5(5.9) \\
13(15.5)\end{array}$ & $\begin{array}{l}80(94.1) \\
70(83.3)\end{array}$ & & (40) \\
\hline
\end{tabular}


Table II. Continued.

A, Type I

\begin{tabular}{|c|c|c|c|c|c|c|c|}
\hline First author (year) & $\begin{array}{c}\text { Disease } \\
\text { type }\end{array}$ & Patients (n) & Intervention & Recurrence & Cure/remission & $\begin{array}{c}\text { Restored } \\
\text { normal flora }\end{array}$ & (Refs.) \\
\hline Anukam (2006a) & $\mathrm{BV}$ & $\begin{array}{l}65 \\
60\end{array}$ & $\begin{array}{c}\text { Probiotic } \\
\text { Control }\end{array}$ & $\begin{array}{c}0(0) \\
17(28)\end{array}$ & $\begin{array}{c}8(12) \\
19(32)\end{array}$ & $\begin{array}{l}57(88) \\
24(40)\end{array}$ & (15) \\
\hline Han (2006) & VVC & $\begin{array}{l}86 \\
90\end{array}$ & $\begin{array}{c}\text { Probiotic } \\
\text { Control }\end{array}$ & $\begin{array}{c}3(3.9) \\
9(13.0)\end{array}$ & $\begin{array}{l}74(96.10) \\
60(86.96)\end{array}$ & & (37) \\
\hline Lin (2006) & VVC & $\begin{array}{l}53 \\
52\end{array}$ & $\begin{array}{c}\text { Probiotic } \\
\text { Control }\end{array}$ & $\begin{array}{c}2(3.8) \\
13(25.0)\end{array}$ & $\begin{array}{l}52(98.1) \\
49(94.2)\end{array}$ & & (31) \\
\hline Lin (2006) & BV & $\begin{array}{l}59 \\
51\end{array}$ & $\begin{array}{c}\text { Probiotic } \\
\text { Control }\end{array}$ & $\begin{array}{c}1(1.7) \\
12(23.5)\end{array}$ & $\begin{array}{l}58(98.3) \\
47(92.2)\end{array}$ & & (31) \\
\hline Eriksson (2005) & BV & $\begin{array}{l}91 \\
96\end{array}$ & $\begin{array}{l}\text { Probiotics } \\
\text { Control }\end{array}$ & & $\begin{array}{l}52(56.8) \\
58(60.2)\end{array}$ & & (18) \\
\hline
\end{tabular}

B, Type II

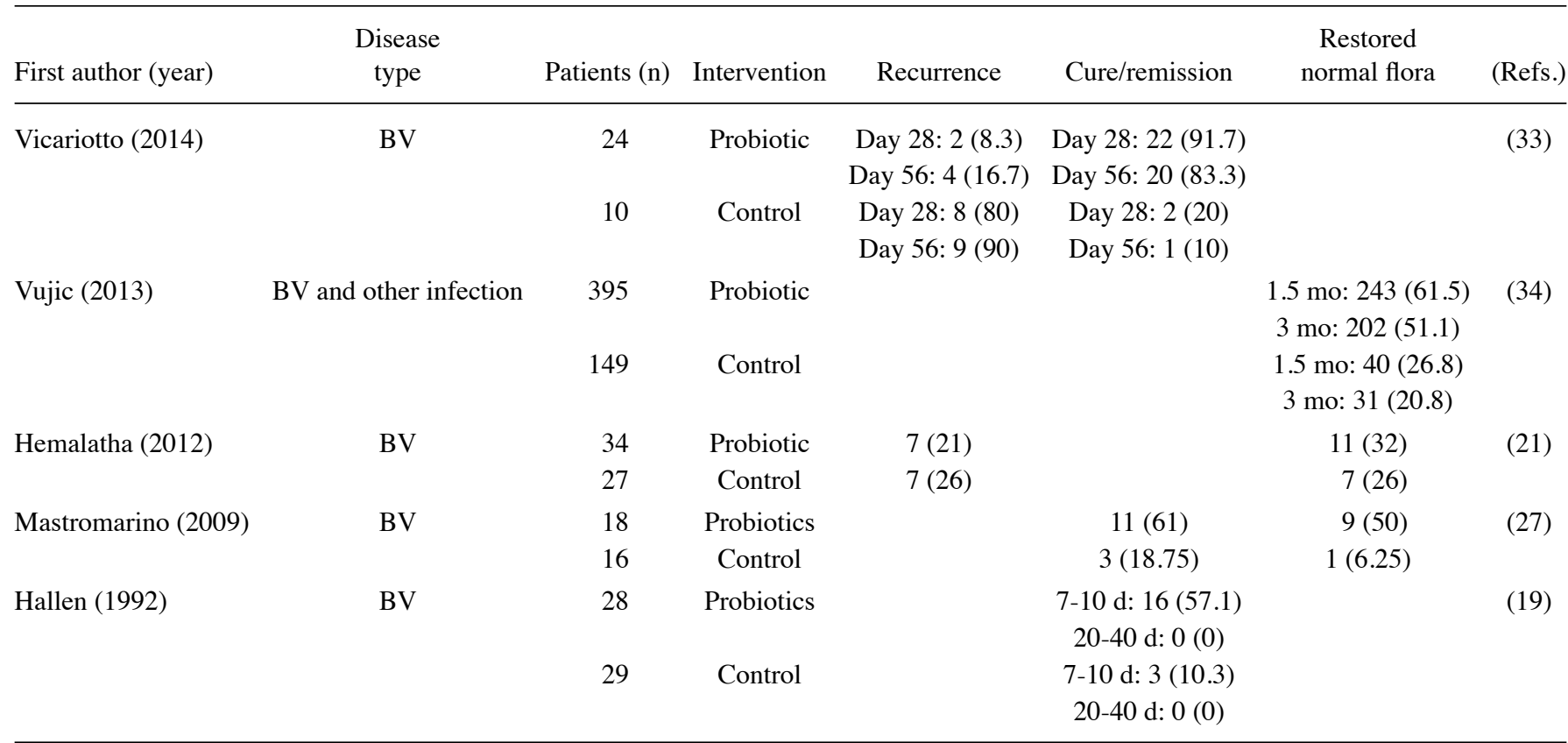

C, Type III

\begin{tabular}{|c|c|c|c|c|c|c|c|}
\hline First author (year) & $\begin{array}{l}\text { Disease } \\
\text { type }\end{array}$ & Patients (n) & Intervention & Recurrence & Cure/remission & $\begin{array}{c}\text { Restored } \\
\text { normal flora }\end{array}$ & (Refs.) \\
\hline Ling (2013) & BV & $\begin{array}{l}25 \\
30\end{array}$ & $\begin{array}{c}\text { Probiotic } \\
\text { Control }\end{array}$ & & & & (30) \\
\hline Anukam (2006b) & BV & $\begin{array}{l}20 \\
20\end{array}$ & $\begin{array}{c}\text { Probiotic } \\
\text { Control }\end{array}$ & $\begin{array}{l}2(10) \\
9(45)\end{array}$ & $\begin{array}{r}15(75) \\
9(45)\end{array}$ & $\begin{array}{r}11(55) \\
6(30)\end{array}$ & (16) \\
\hline Parent (1996) & BV & $\begin{array}{l}16 \\
16\end{array}$ & $\begin{array}{l}\text { Probiotics } \\
\text { Control }\end{array}$ & & $\begin{array}{r}14(87.5) \\
4(22.2)\end{array}$ & & $(28)$ \\
\hline
\end{tabular}

Values are expressed as $\mathrm{n}$ for patients' number, $\mathrm{n}(\%)$ for recurrence, cure/remission, and restored normal flora. mo, months; d, days; BV, bacterial vaginosis; VVC, vulvovaginal candidiasis; AV, aerobic vaginitis; Ref., reference.

The analysis indicated that probiotic treatment was favorable among all studies and those focusing on VVC alone 1 month after treatment (total: Pooled OR=2.28, 95\% CI: $1.21-4.32$,
$\mathrm{P}=0.011$; VVC: Pooled OR=1.72, 95\% CI: 1.13-2.64, $\mathrm{P}=0.012$ ), as well as 6 months after treatment of $\mathrm{BV}$ (pooled $\mathrm{OR}=2.58$, 95\% CI: $1.07-6.23, \mathrm{P}=0.036$; Fig. 2B). However, there was 


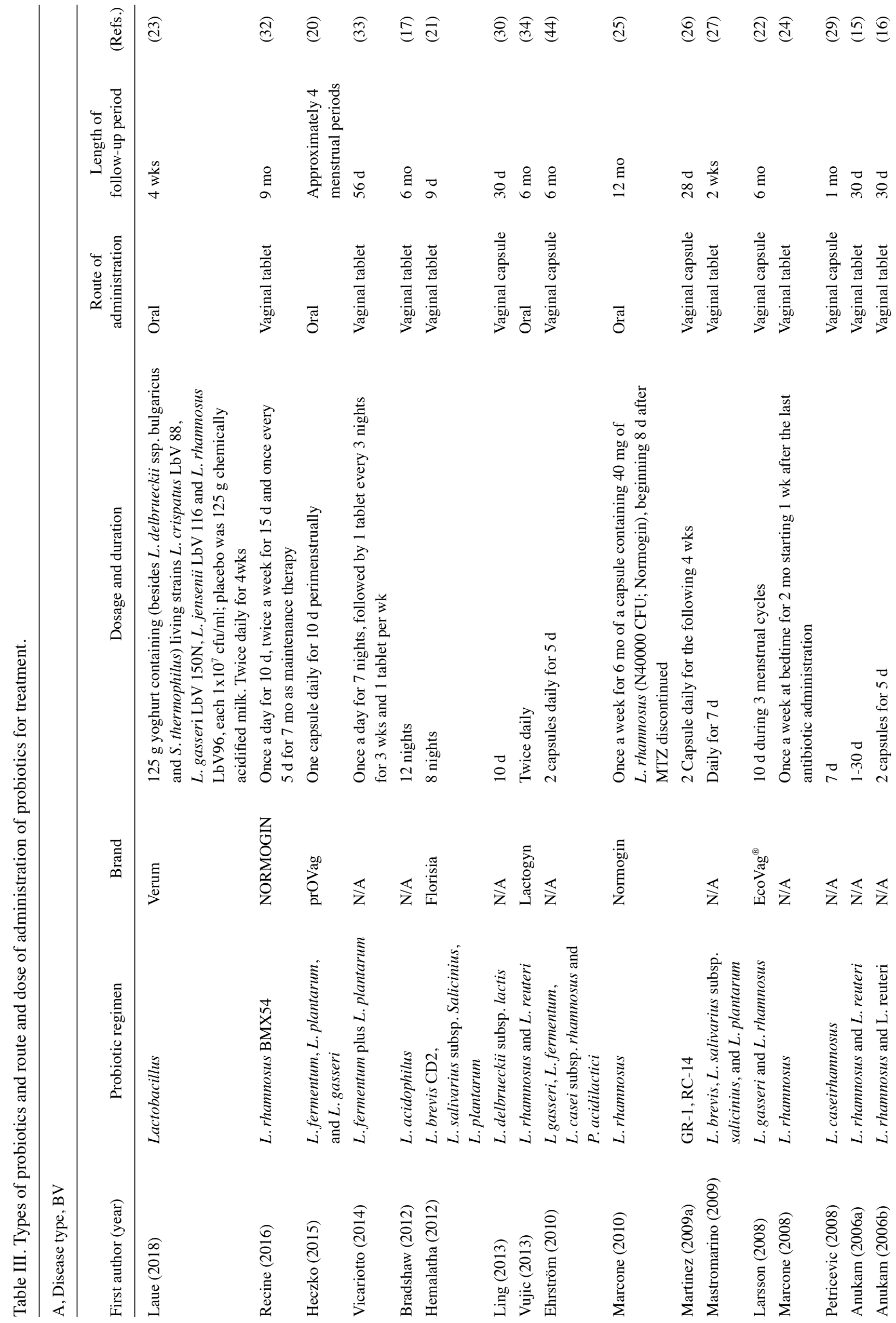




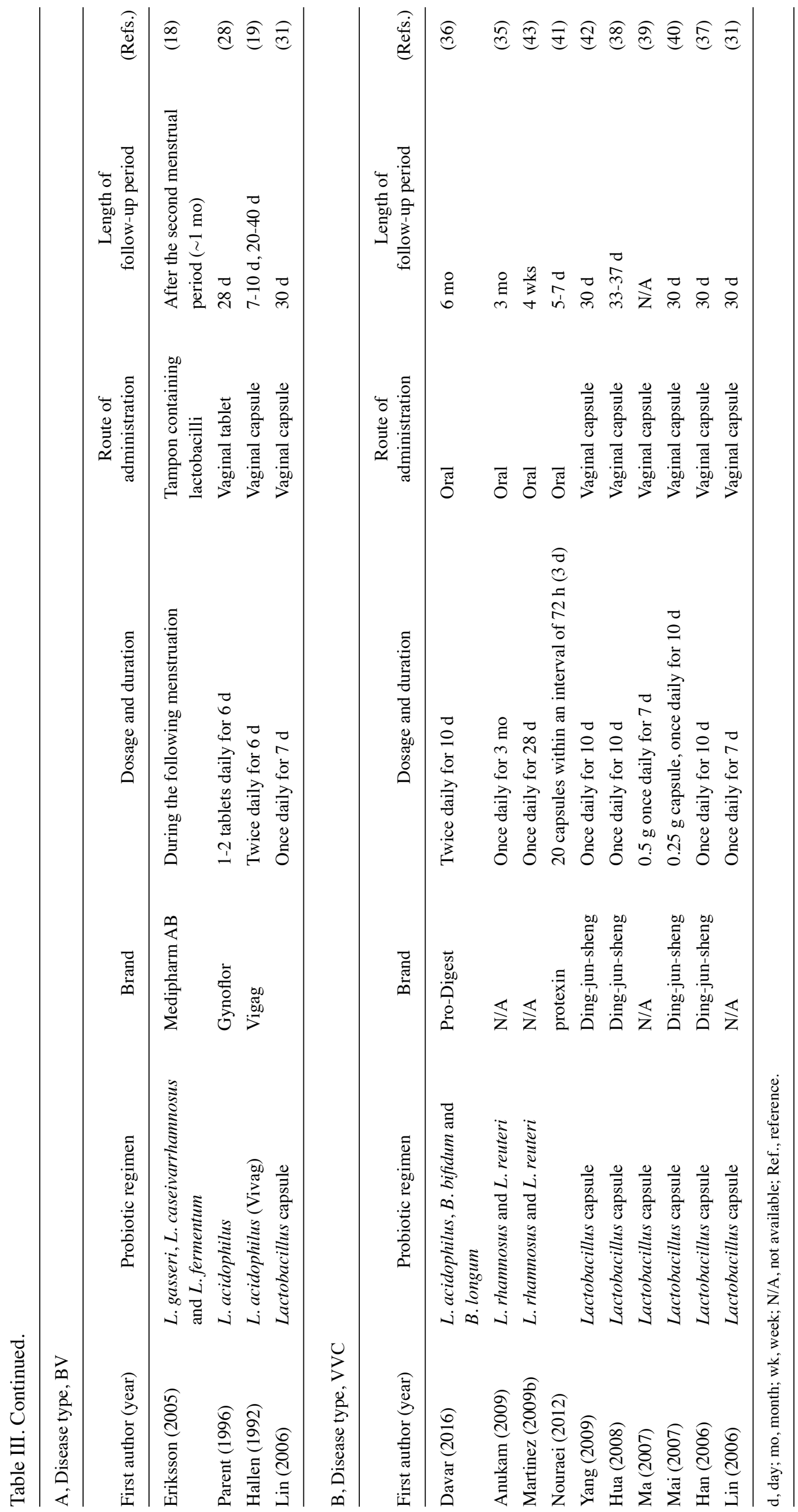


A Recurrence

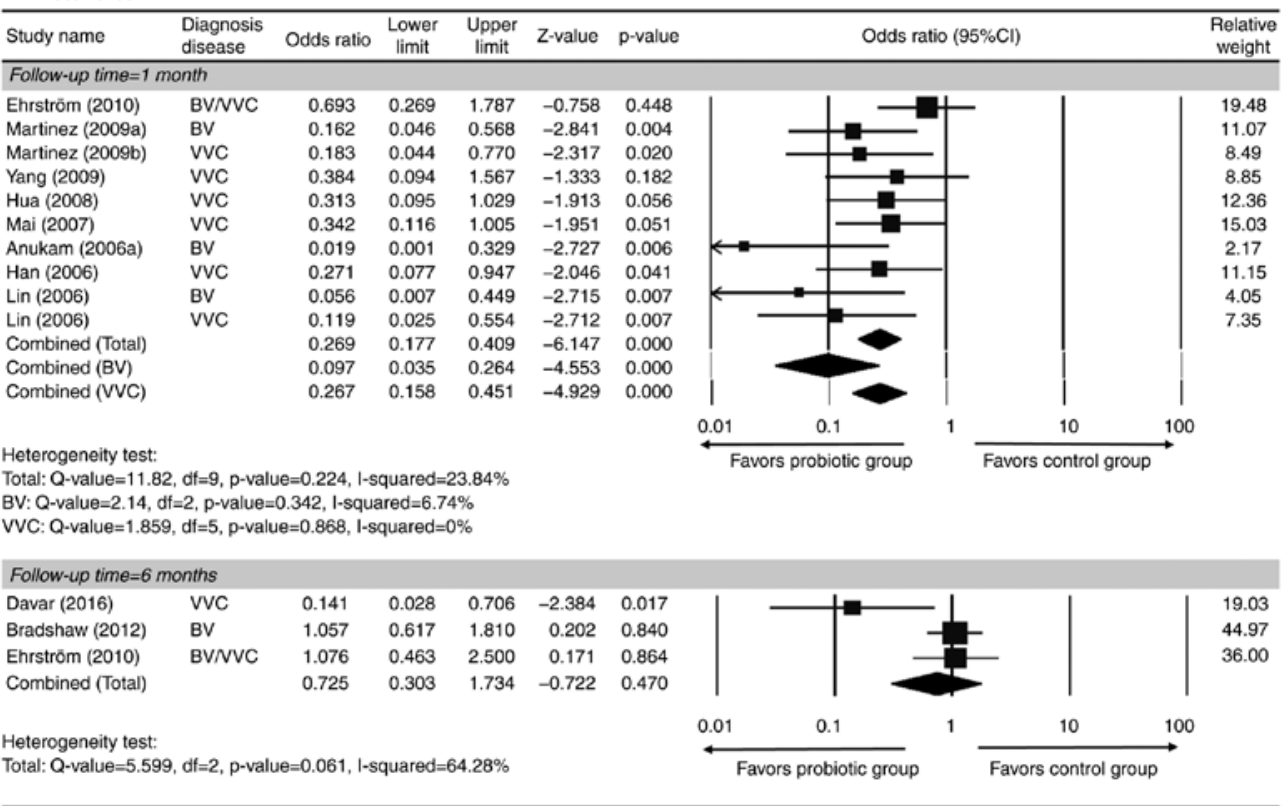

B Cure/remission

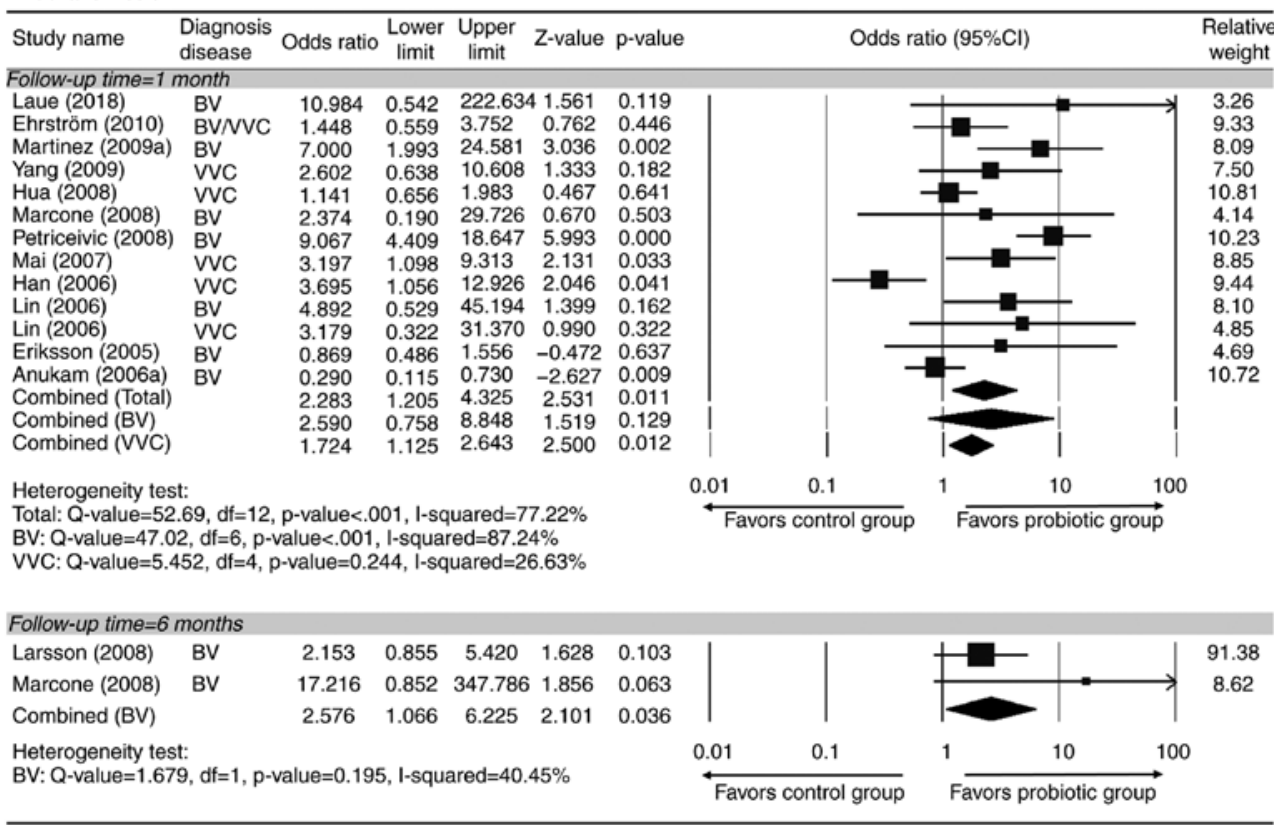

C Restoration of normal flora

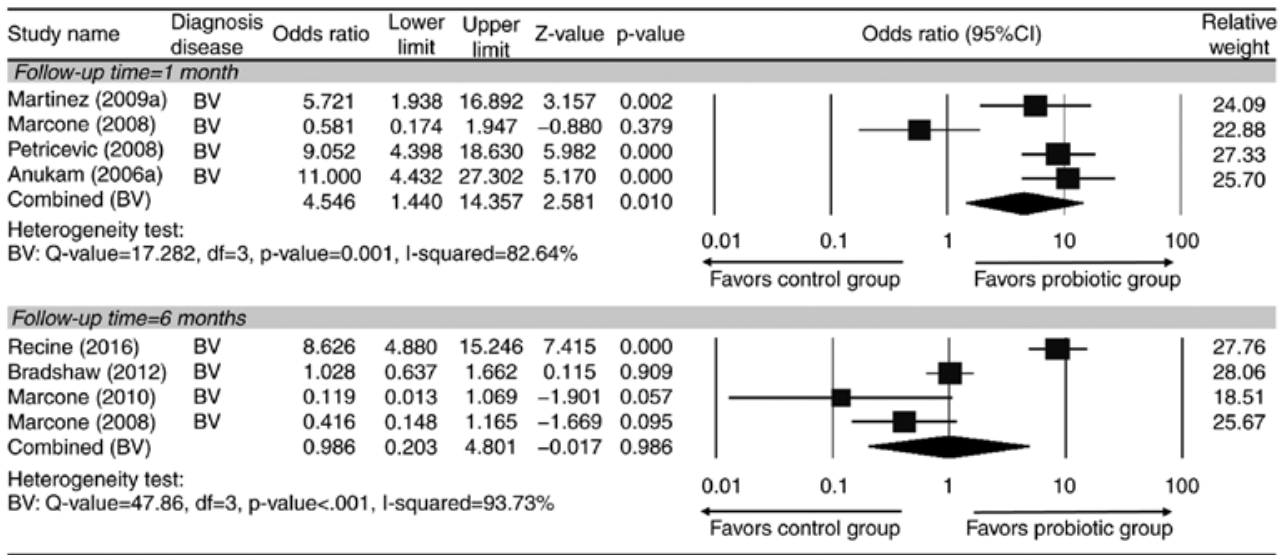

Figure 2. Forest plots for antibiotic plus Lactobacillus vs. antibiotic plus placebo (type I study) in the treatment of bacterial vaginosis and vulvovaginal candidiasis: (A) 1-month and 6-month recurrence rate; (B) 1-month and 6-month cure or remission rate; (C) restoration of normal flora after 1 month of follow-up. $\mathrm{BV}$, bacterial vaginosis; VVC, vulvovaginal candidiasis; df, degrees of freedom. 

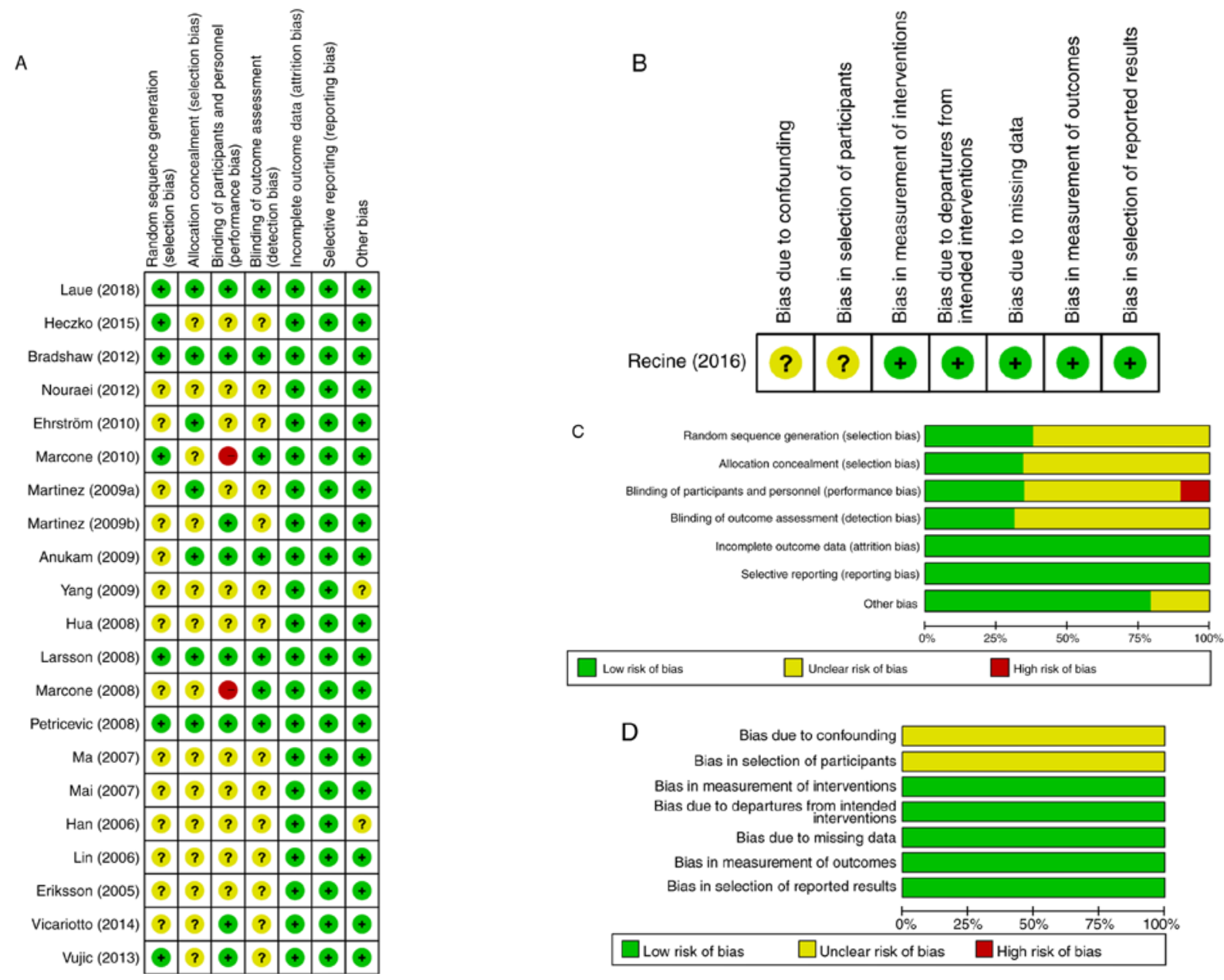

Figure 3. Quality assessment of included studies. Risk of bias summary of (A) randomized controlled trials and (B) non-randomized controlled trials. Risk of bias graph of (C) randomized controlled trials and (D) non-randomized controlled trials.

no significant difference in the cure rate at 1 month for $\mathrm{BV}$ (pooled OR=2.59; 95\% CI: 0.76-8.85; P=0.129; Fig. 2B).

With respect to restoration of the normal flora, 4 studies $(15,24,26,29)$ had complete quantitative data at 1 month and 4 studies $(17,24,25,32)$ at 6 months after treatments for BV, and were included in the analysis. High heterogeneity existed among the studies on the restoration of normal flora at 1 month and 6 months after treatment ( 1 month: $\mathrm{Q}=17.28, \mathrm{I}^{2}=83 \%$; 6 months: $\mathrm{Q}=47.86, \mathrm{I}^{2}=94 \%$ ). The analysis indicated that patients in the probiotic group had a significantly higher rate of normal flora restoration at 1 month after treatment (pooled $\mathrm{OR}=4.55,95 \%$ CI: 1.44-14.36, $\mathrm{P}=0.010$ ). However, there were no differences in the normal flora restoration rate between the two groups at 6 months after treatment (Fig. 2C).

Additional analyses were performed for type II $(19,21,27,33,34)$ or type III $(16,28)$ studies that had at least one follow-up outcome. These studies all focused on BV and had varied heterogeneity (Recurrence: $\mathrm{Q}=7.98 ; \mathrm{I}^{2}=87 \%$; Cure or remission: $\mathrm{Q}=1.94 ; \mathrm{I}^{2}=0 \%$; Restored normal flora: $\mathrm{Q}=4.37$; $\mathrm{I}^{2}=54 \%$ for type II and Cure or remission: $\mathrm{Q}=2.58 ; \mathrm{I}^{2}=61 \%$; for type III). Patients with BV given type II treatments in the probiotic group were indicated to have a higher cure or remission rate and normal flora restoration rate than those in the control group (cure/remission rate: Pooled $\mathrm{OR}=12.44$, 95\% CI: 4.86-31.89, $\mathrm{P}<0.001$; normal flora restoration rate:
Pooled OR=3.32, 95\% CI: 1.11-9.97, $\mathrm{P}=0.033)$. In BV patients given type III treatments, the probiotic group had a higher cure/remission rate than the control group (cure/remission rate: Pooled OR=8.39, 95\% CI: 1.32-53.23, P=0.024; Table IV).

Quality assessment. The risk of bias assessment for individual studies is provided in Fig. 3, including the potential risk of individual studies (Fig. 3A and B) and the overall risk (Fig. 3C and D). Overall, the studies had a low risk of attrition bias and reporting bias, and low or unclear risk of selection bias and detection bias. Furthermore, 3 studies had a high risk of performance bias due to improper blinding of participants and researchers.

Sensitivity analysis. Sensitivity analyses were performed on the major results using the leave-one-out approach, in which the meta-analysis was performed with each study removed in turn (Table V). The direction of combined estimates on recurrence rates and cure/remission rates at 1 month and normal flora restoration rates at 6 months did not vary markedly with the removal of the studies, indicating that the meta-analysis had good reliability and supported that there was no or little inter-study heterogeneity. However, for normal flora restoration rates at 1 month, the study of Marcone et al (24) from 2008 may have had a disproportionate effect on the pooled $\mathrm{OR}$, as the difference became more significant and greater 


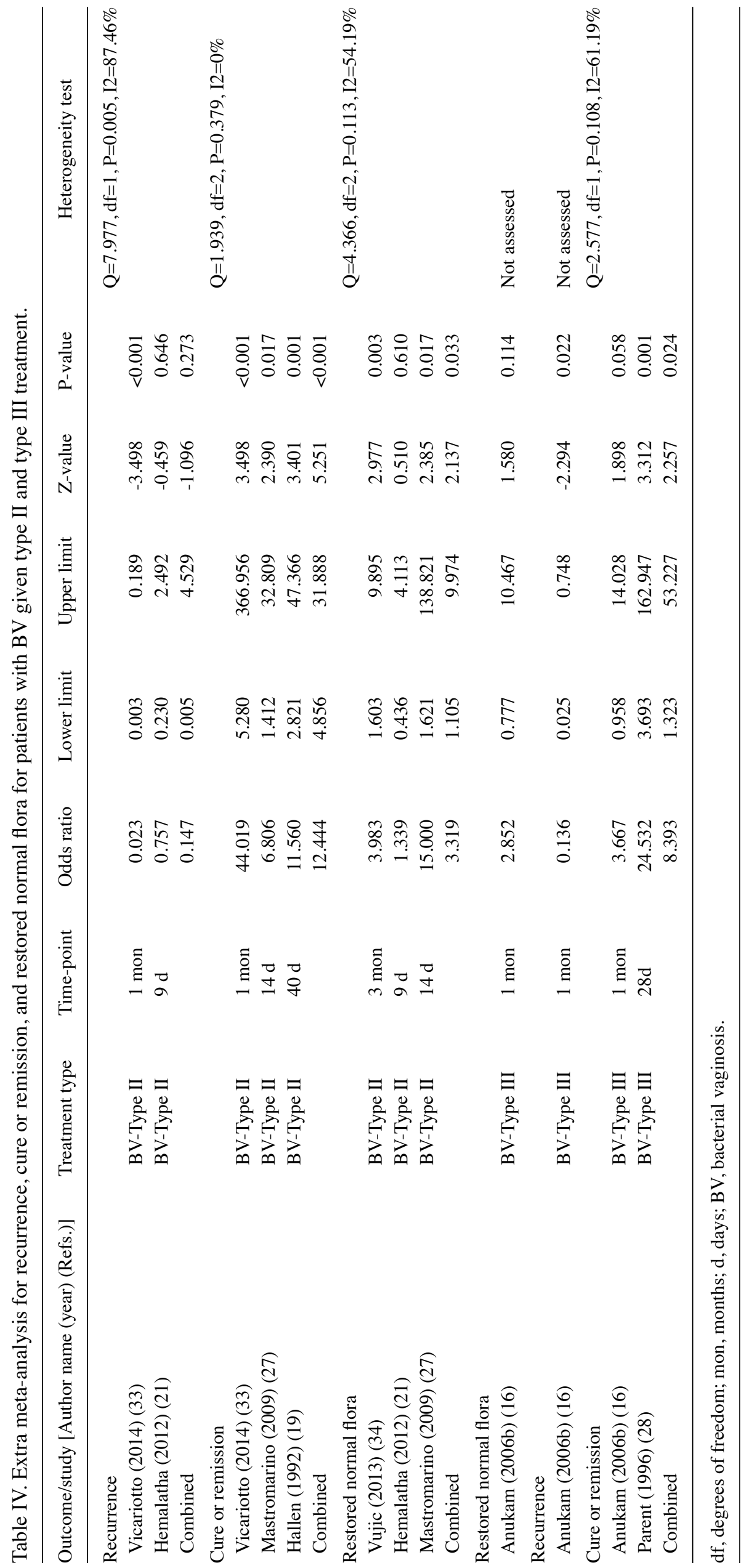


Table V. Sensitivity analysis.

A, Recurrence at 1 month

Statistics with study removed

\begin{tabular}{|c|c|c|c|c|c|c|}
\hline \multirow[b]{2}{*}{ Author name (year) } & & & & & & \multirow[b]{2}{*}{ (Refs.) } \\
\hline & Odds ratio & Lower limit & Upper limit & Z-value & $\mathrm{P}$-value & \\
\hline Ehrström (2010) & 0.214 & 0.135 & 0.342 & -6.478 & $<0.001$ & (44) \\
\hline Martinez (2009a) & 0.287 & 0.184 & 0.447 & -5.516 & $<0.001$ & $(26)$ \\
\hline Martinez (2009b) & 0.279 & 0.180 & 0.432 & -5.720 & $<0.001$ & (43) \\
\hline Yang (2009) & 0.260 & 0.168 & 0.403 & -6.023 & $<0.001$ & $(42)$ \\
\hline Hua (2008) & 0.264 & 0.169 & 0.412 & -5.848 & $<0.001$ & (38) \\
\hline Mai (2007) & 0.258 & 0.164 & 0.407 & -5.848 & $<0.001$ & $(40)$ \\
\hline Anukam (2006a) & 0.286 & 0.187 & 0.436 & -5.809 & $<0.001$ & (15) \\
\hline Han (2006) & 0.269 & 0.173 & 0.420 & -5.797 & $<0.001$ & (37) \\
\hline Lin (2006) & 0.288 & 0.188 & 0.441 & -5.718 & $<0.001$ & $(31)$ \\
\hline Lin (2006) & 0.288 & 0.186 & 0.444 & -5.622 & $<0.001$ & $(31)$ \\
\hline
\end{tabular}

$\mathrm{B}$, Cure or remission at 1 month

Statistics with study removed

\begin{tabular}{|c|c|c|c|c|c|c|}
\hline \multirow[b]{2}{*}{ Author name (year) } & & \multirow[b]{2}{*}{ (Refs.) } \\
\hline & Odds ratio & Lower limit & Upper limit & Z-value & P-value & \\
\hline Laue (2018) & 2.165 & 1.131 & 4.146 & 2.330 & 0.020 & (23) \\
\hline Ehrström (2010) & 2.416 & 1.197 & 4.879 & 2.461 & 0.014 & (44) \\
\hline Martinez (2009a) & 2.062 & 1.069 & 3.979 & 2.158 & 0.031 & (26) \\
\hline Yang (2009) & 2.271 & 1.150 & 4.486 & 2.361 & 0.018 & $(42)$ \\
\hline Hua (2008) & 2.521 & 1.209 & 5.256 & 2.467 & 0.014 & (38) \\
\hline Marcone (2008) & 2.286 & 1.179 & 4.431 & 2.447 & 0.014 & (24) \\
\hline Petricevic (2008) & 1.818 & 1.047 & 3.155 & 2.123 & 0.034 & (29) \\
\hline Mai (2007) & 2.224 & 1.117 & 4.427 & 2.275 & 0.023 & $(40)$ \\
\hline Han (2006) & 2.764 & 1.523 & 5.015 & 3.345 & 0.001 & $(37)$ \\
\hline Lin (2006) & 2.197 & 1.114 & 4.333 & 2.271 & 0.023 & $(31)$ \\
\hline Lin (2006) & 2.199 & 1.136 & 4.259 & 2.337 & 0.019 & (31) \\
\hline Eriksson (2005) & 2.252 & 1.160 & 4.372 & 2.398 & 0.016 & (18) \\
\hline Anukam (2006a) & 2.578 & 1.280 & 5.193 & 2.651 & 0.008 & (15) \\
\hline
\end{tabular}

$\mathrm{C}$, Restoration of normal flora at 1 month

Statistics with study removed

\begin{tabular}{lcccrrr}
\cline { 2 - 5 } Author name (year) & Odds ratio & Lower limit & Upper limit & Z-value & P-value & (Refs.) \\
\hline Martinez (2009a) & 4.121 & 0.853 & 19.905 & 1.762 & 0.078 \\
Marcone (2008) & 8.705 & 5.274 & 14.368 & 8.464 & $<0.001$ \\
Petricevic (2008) & 3.442 & 0.646 & 18.335 & 1.448 & 0.148 \\
Anukam (2006a) & 3.284 & 0.692 & 15.591 & 1.496 & 0.135 \\
\hline
\end{tabular}

D, Restoration of normal flora at 6 months

Statistics with study removed

\begin{tabular}{|c|c|c|c|c|c|c|}
\hline \multirow[b]{2}{*}{ Author name (year) } & & & & & & \multirow[b]{2}{*}{ (Refs.) } \\
\hline & Odds ratio & Lower limit & Upper limit & Z-value & $\mathrm{P}$-value & \\
\hline Recine (2016) & 0.536 & 0.195 & 1.477 & -1.205 & 0.228 & (32) \\
\hline Bradshaw (2012) & 0.861 & 0.062 & 11.885 & -0.112 & 0.911 & (17) \\
\hline
\end{tabular}


Table V. Continued.

$\mathrm{D}$, Restoration of normal flora at 6 months

Statistics with study removed

\begin{tabular}{lcccccr}
\cline { 2 - 4 } Auth name (year) & Odds ratio & Lower limit & Upper limit & Z-value & P-value & (Refs.) \\
\hline Marcone (2010) & 1.599 & 0.293 & 8.737 & 0.542 & 0.588 \\
Marcone (2008) & 1.312 & 0.197 & 8.715 & 0.281 & 0.779 \\
\hline
\end{tabular}

$\mathrm{BV}$, bacterial vaginosis.

when this study was not included in the meta-analysis, while the three other studies had no such effect.

\section{Discussion}

The overall summary of the qualitative analysis of the 30 studies suggests that probiotic treatments are useful for managing common vaginal infections, particularly BV and VVC. However, patient populations, treatment protocols, endpoints and follow-up time-points exhibited a marked variation. The results of the meta-analysis indicated that probiotics as a supplement of antibiotic/anti-fungal treatments (as observed in type I studies) reduced the recurrence rate and increased the cure/remission rate in non-pregnant adult females at 1 month after treatment. With less evident data, the normal bacterial flora restoration rate was also increased by probiotic-supplemented treatments in BV. The short-term benefits of probiotics were further supported by individual analysis of BV and VVC, although probiotics supplementary to standard treatments did not increase the cure/remission rate in $\mathrm{BV}$ and the post-treatment normal bacterial restoration rate in VVC was lacking. However, observations at 6 months post-treatment were less frequently reported. In line with the results demonstrated by probiotic-supplemented treatments, probiotics alone without antibiotics may have clinical benefits in promoting the cure/remission rate and normal flora restoration rates in $\mathrm{BV}$.

To the best of our knowledge, the present meta-analysis was the first to review and analyze the effect of probiotics in common vaginal infections reported by RCTs or appropriately-controlled studies. Furthermore, only few studies have evaluated the benefits of probiotics in vaginal infection stratified by treatment regimen. The quantitative data of the present study are supported by conclusions from two published systemic reviews, which examined the overall effect of probiotics in females with urogenital infections qualitatively. In 2009, Abad and Safdar (6) identified 25 studies that used Lactobacillus-containing probiotics to either prevent or treat a urogenital infection [BV, VVC and urinary tract infections (UTI)]. Of the 25 studies, 18 used Lactobacillus preparations for the treatment or prevention of urogenital infections and 7 focused solely on vaginal colonization (6). Of the 18 studies, only 8 studies included patients with BV, 4 included patients with VVC, 5 included patients with UTI and 1 was on multiple infections (6). Overall, Lactobacilli were beneficial for the treatment of $\mathrm{BV}$, while no clear benefit was observed for VVC or UTI (6). A more recent systematic review published in 2016 investigated probiotics for the treatment and prevention of urogenital infections in females (4). A total of 20 studies (published from 2008 to 2015) were identified, with 14 examining BV, 2 examining VCC, 3 examining UTI and 1 examining human papillomavirus (HPV) (4). While the studies reviewed by Hanson et al (4) in 2016 were heterogeneous with respect to study type, design, intervention and outcomes and varied in quality (4 of good quality, 9 of fair and 7 of poor quality), the authors still made to the conclusion that the use of probiotics may be effective for the treatment and prevention of BV, recurrent candidiasis or UTI, as well as HPV lesions. In the current review, an analysis of quantitative outcomes from a total of 1,788 patients with common vaginal infections was presented, with focus on $\mathrm{BV}$ and VVC that are most directly impacted by an imbalanced microflora/dysbiosis.

One prior meta-analysis examined the use of probiotics for treating BV. In a meta-analysis published in 2014, Huang et al (3) indicated that the use of probiotic supplementation significantly improved the cure rate in adult females with BV [risk ratio (RR)=1.53; 95\% CI: 1.19-1.97]. When only 9 high-quality studies were included in the analysis, the RR increased slightly to 1.60 (95\% CI: 1.16-2.22) (3). Of note, when a subgroup analysis was performed, a single treatment with probiotics may only be effective for short-term follow-up ( $\leq 1$ month) but not for long-term follow-up (>1 month) (3), which was consistent with the present result that no difference between two groups in recurrence rate and cure/remission rates was determined at 6 months after the treatment. In a meta-analysis by Huang et al (3) from 2014, the eligible articles were searched up to May 2013 and the studies included in the meta-analysis were also heterogeneous. In the present meta-analysis, the literature search was further updated to December 24th, 2018, and studies all except one RCT analyzed in the previous study by Huang et al (3) from 2014 were included. This particular RCT was excluded from the present study due to its study design for healthy females with a history of BV (45); furthermore, it had different follow-up time-points from other studies analyzed in the present study and was deemed unsuitable for analysis of post-treatment outcomes.

A recent meta-analysis study suggested that, although probiotics appeared effective in treating VVC, relevant studies were not sufficient in number (5-7 studies included for each analysis) or of comparable quality (7). In the present study, 
which focused on common vaginal infections as a whole, only studies with comparable treatment designs and study follow-up schedules were included in the meta-analysis. Furthermore, the major results of the present study were based on $>10$ RCTs or prospective studies with control arms. In 2006, Falagas et al (46) reported on several clinical trials on VVC that support the effectiveness of Lactobacilli administered either orally or intravaginally in decreasing colonization of C. albicans or preventing vaginal candidiasis. However, most of the relevant clinical trials had methodological problems, including small sample size, no control group (single-arm) and included females without confirmed recurrent VVC. All of the studies on VVC reviewed in the present meta-analysis were designed to compare Lactobacillus capsule-supplemented anti-fungal treatments (probiotic group) with anti-fungal agents alone (control group). Despite the follow-up period ranging from $<1$ week to 6 months among the studies included, only those with comparable follow-up schedules were included in the present meta-analysis. The outcome supports the effectiveness of Lactobacilli in decreasing the recurrence rate and improving the cure rate.

The primary limitation of the present study has already been mentioned-the large heterogeneity between studies with respect to the patient population, type of treatment, probiotic strains and outcome follow-ups. However, it was sought to overcome this by carefully-planned stratification based on treatment design and follow-up schedules. The major results on short-term benefits of combined therapy of antibiotics/anti-fungals with probiotics was further confirmed by the sensitivity test. By contrast, the limited sample size and heterogeneous study design prevented us from a reliable subgroup analysis of long-term benefits and of probiotics treatment alone without antibiotic/anti-fungal agents.

In conclusion, the results of the present study confirm the results of other reports in a quantitative manner, namely that probiotics as a supplement to conventional pharmacological treatments are effective in the short term for the treatment of common vaginal infections in non-pregnant adult females. However, high-quality evidence for the effectiveness of probiotics alone in recurrent or curative vaginal infections is limited. Further high-quality clinical trials are necessary to identify the most effective probiotic strains, the most effective treatment regimens (with or without antibiotics) and the subpopulations of females (e.g. pre-menopausal vs. post-menopausal) that may benefit the most from probiotics.

\section{Acknowledgements}

Not applicable.

\section{Funding}

No funding was received.

\section{Availability of data and materials}

The datasets used and/or analyzed during the present study are available from the corresponding author on reasonable request.

\section{Authors' contributions}

HSJ conceived and designed the current study, defined the content of the research, conducted literature research, performed statistical analysis and prepared and edited the manuscript. TRY is the guarantor of study integrity, designed the current study, defined the content of the research and reviewed the manuscript. JYC conducted literature research, acquired data and performed statistical analysis. All authors read and approved the final manuscript.

\section{Ethics approval and consent to participate}

Not applicable.

\section{Patient consent for publication}

Not applicable.

\section{Competing interests}

The authors declare that there are no competing interests.

\section{References}

1. Kent HL: Epidemiology of vaginitis. Am J Obstet Gynecol 165: 1168-1176, 1991

2. Mills BB: Vaginitis: Beyond the Basics. Obstet Gynecol Clin North Am 44: 159-177, 2017.

3. Huang H, Song L and Zhao W: Effects of probiotics for the treatment of bacterial vaginosis in adult women: A meta-analysis of randomized clinical trials. Arch Gynecol Obstet 289: 1225-1234, 2014.

4. Hanson L, VandeVusse L, Jermè M, Abad CL and Safdar N: Probiotics for treatment and prevention of urogenital infections in women: A systematic review. J Midwifery Womens Health 61: 339-355, 2016.

5. Reid G: Probiotic use in an infectious disease setting. Expert Rev Anti Infect Ther 15: 449-455, 2017.

6. Abad CL and Safdar N: The role of Lactobacillus probiotics in the treatment or prevention of urogenital infections-a systematic review. J Chemother 21: 243-252, 2009.

7. Xie HY, Feng D, Wei DM, Mei L, Chen H, Wang X and Fang F: Probiotics for vulvovaginal candidiasis in non-pregnant women. Cochrane Database Syst Rev 11: CD010496, 2017.

8. Liberati A, Altman DG, Tetzlaff J, Mulrow C, Gøtzsche PC, Ioannidis JP, Clarke M, Devereaux PJ, Kleijnen J and Moher D: The PRISMA statement for reporting systematic reviews and meta-analyses of studies that evaluate health care interventions: Explanation and elaboration. J Clin Epidemiol 62: e1-e34, 2009.

9. Higgins JP: Commentary: Heterogeneity in meta-analysis should be expected and appropriately quantified. Int J Epidemiol 37: 1158-1160, 2008.

10. Sterne JAC, Higgins JPT, Reeves BC on behalf of the development group for ACROBAT- NRSI. A Cochrane Risk Of Bias Assessment Tool: for Non-Randomized Studies of Interventions (ACROBAT- NRSI), Version 1.0.0, 24 September 2014. http://www.riskofbias.info.

11. Deeks JJ, Higgins JPT and DG A: Chapter 10: Analysing data and undertaking meta-analyses. In: Cochrane Handbook for Systematic Reviews of Interventions version 6.0 (updated July 2019). Higgins JPT, Thomas J, Chandler J, et al. (eds.) Cochrane, 2019.

12. Hardy RJ and Thompson SG: Detecting and describing heterogeneity in meta-analysis. Stat Med 17: 841-856, 1998.

13. Takkouche B, Cadarso-Suárez C and Spiegelman D: Evaluation of old and new tests of heterogeneity in epidemiologic meta-analysis. Am J Epidemiol 150: 206-215, 1999.

14. National Research Council: Combining Information: Statistical issues and opportunities for research. The National Academies Press, Washington, DC, 1992. https://doi.org/10.17226/20865. 
15. Anukam K, Osazuwa E, Ahonkhai I, Ngwu M, Osemene G, Bruce AW and Reid G: Augmentation of antimicrobial metronidazole therapy of bacterial vaginosis with oral probiotic Lactobacillus rhamnosus GR-1 and Lactobacillus reuteri RC-14: Randomized, double-blind, placebo controlled trial. Microbes Infect 8: 1450-1454, 2006.

16. Anukam KC, Osazuwa E, Osemene GI, Ehigiagbe F, Bruce AW and Reid G: Clinical study comparing probiotic Lactobacillus GR-1 and RC-14 with metronidazole vaginal gel to treat symptomatic bacterial vaginosis. Microbes Infect 8: 2772-2776, 2006

17. Bradshaw CS, Pirotta M, De Guingand D, Hocking JS, Morton AN, Garland SM, Fehler G, Morrow A, Walker S, Vodstrcil LA and Fairley CK: Efficacy of oral metronidazole with vaginal clindamycin or vaginal probiotic for bacterial vaginosis: Randomised placebo-controlled double-blind trial. PLoS One 7: e34540, 2012.

18. Eriksson K, Carlsson B, Forsum U and Larsson PG: A doubleblind treatment study of bacterial vaginosis with normal vaginal lactobacilli after an open treatment with vaginal clindamycin ovules. Acta Derm Venereol 85: 42-46, 2005

19. Hallen A, Jarstrand C and Påhlson C: Treatment of bacterial vaginosis with lactobacilli. Sex Transm Dis 19: 146-148, 1992.

20. Heczko PB, Tomusiak A, Adamski P, Jakimiuk AJ, Stefanski G, Mikołajczyk-Cichońska A, Suda-Szczurek M and Strus M: Supplementation of standard antibiotic therapy with oral probiotics for bacterial vaginosis and aerobic vaginitis: A randomised, double-blind, placebo-controlled trial. BMC Womens Health 15: $115,2015$.

21. Hemalatha R, Mastromarino P, Ramalaxmi BA, Balakrishna NV and Sesikeran B: Effectiveness of vaginal tablets containing lactobacilli versus $\mathrm{pH}$ tablets on vaginal health and inflammatory cytokines: A randomized, double-blind study. Eur J Clin Microbiol Infect Dis 31: 3097-3105, 2012

22. Larsson PG, Stray-Pedersen B, Ryttig KR and Larsen S: Human lactobacilli as supplementation of clindamycin to patients with bacterial vaginosis reduce the recurrence rate; a 6-month, double-blind, randomized, placebo-controlled study. BMC Womens Health 8: 3, 2008.

23. Laue C, Papazova E, Liesegang A, Pannenbeckers A, Arendarski P, Linnerth B, Domig KJ, Kneifel W, Petricevic L and Schrezenmeir J: Effect of a yoghurt drink containing Lactobacillus strains on bacterial vaginosis in women-a double-blind, randomised, controlled clinical pilot trial. Benef Microbes 9: 35-50, 2018.

24. Marcone V, Calzolari E and Bertini M: Effectiveness of vaginal administration of Lactobacillus rhamnosus following conventional metronidazole therapy: How to lower the rate of bacterial vaginosis recurrences. New Microbiol 31: 429-433, 2008.

25. Marcone V, Rocca G, Lichtner M and Calzolari E: Long-term vaginal administration of Lactobacillus rhamnosus as a complementary approach to management of bacterial vaginosis. Int J Gynaecol Obstet 110: 223-226, 2010.

26. Martinez RC, Franceschini SA, Patta MC, Quintana SM, Gomes BC, De Martinis EC and Reid G: Improved cure of bacterial vaginosis with single dose of tinidazole $(2 \mathrm{~g})$, Lactobacillus rhamnosus GR-1, and Lactobacillus reuteri RC-14: a randomized, double-blind, placebo-controlled trial. Can J Microbiol 55: $133-138,2009$.

27. Mastromarino P, Macchia S, Meggiorini L, Trinchieri V, Mosca L, Perluigi $M$ and Midulla C: Effectiveness of Lactobacillus-containing vaginal tablets in the treatment of symptomatic bacterial vaginosis. Clin Microbiol Infect 15: 67-74, 2009.

28. Parent D, Bossens M, Bayot D, Kirkpatrick C, Graf F, Wilkinson FE and Kaiser RR: Therapy of bacterial vaginosis using exogenously-applied Lactobacilli acidophili and a low dose of estriol: A placebo-controlled multicentric clinical trial. Arzneimittelforschung 46: 68-73, 1996.

29. Petricevic L and Witt A: The role of Lactobacillus casei rhamnosus Lcr35 in restoring the normal vaginal flora after antibiotic treatment of bacterial vaginosis. BJOG 115: 1369-1374, 2008.

30. Ling Z, Liu X, Chen W, Luo Y, Yuan L, Xia Y, Nelson KE, Huang S, Zhang S, Wang Y, et al: The restoration of the vaginal microbiota after treatment for bacterial vaginosis with metronidazole or probiotics. Microb Ecol 65: 773-780, 2013.
31. Lin H and Meng XB: Clinical application of Lactasin capsules in vaginitis. J Practical Medicine 22: 1927-1928, 2006.

32. Recine N, Palma E, Domenici L, Giorgini M, Imperiale L, Sassu C, Musella A, Marchetti C, Muzii L and Benedetti Panici P: Restoring vaginal microbiota: Biological control of bacterial vaginosis. A prospective case-control study using Lactobacillus rhamnosus BMX 54 as adjuvant treatment against bacterial vaginosis. Arch Gynecol Obstet 293: 101-107, 2016.

33. Vicariotto F, Mogna L and Del Piano M: Effectiveness of the two microorganisms Lactobacillus fermentum LF15 and Lactobacillus plantarum LP01, formulated in slow-release vaginal tablets, in women affected by bacterial vaginosis: A pilot study. J Clin Gastroenterol 48 (Suppl 1): S106-S112, 2014.

34. Vujic G, Jajac Knez A, Despot Stefanovic V and Kuzmic Vrbanovic V: Efficacy of orally applied probiotic capsules for bacterial vaginosis and other vaginal infections: A double-blind, randomized, placebo-controlled study. Eur J Obstet Gynecol Reprod Biol 168: 75-79, 2013.

35. Anukam KC, Duru MU, Eze CC, Egharevba J, Aiyebelehin A, Bruce A and Reid G: Oral use of probiotics as an adjunctive therapy to fluconazole in the treatment of yeast vaginitis: A study of Nigerian women in an outdoor clinic. Microbial Ecol Health Dis 21: 72-77, 2009.

36. Davar R, Nokhostin F, Eftekhar M, Sekhavat L, Bashiri Zadeh M and Shamsi F: Comparing the recurrence of vulvovaginal candidiasis in patients undergoing prophylactic treatment with probiotic and placebo during the 6 months. Probiotics Antimicrob Proteins 8: 130-133, 2016.

37. Han YX and Zhao SW: Clinical observation of Ding JunSheng and clotrimazole vaginal tablet in the treatment ofvulvovaginal candidiasis. Anh Med J 27: 528-529, 2006.

38. Hua Y, Lin M, Wang L and Xia L: Observation of curative effect of miconazole and Lactobacillus on vulvovaginal candidiasis treated. Chin J Microecol 20: 386-387, 2008.

39. Ma L and Li L: Miconazole plus Lactasin capsules to treat vulvovaginal candidiasis (54 cases). Herald Med 26: 1041-1042, 2007.

40. Mai XY: Analysis of probiotic Lactobacillus's effect on vulvovaginal candidiasis. Chin J Microecol 19: 362-363, 2007.

41. Nouraei S, Amir Ali Akbari S, Jorjani M, Alavi Majd H, Afrakhteh M, Ghafoorian A and Tafazzoli Harandi $\mathrm{H}$ : Comparison between fluconazole with oral protexin combination and fluconazole in the treatment of vulvovaginal candidiasis. ISRN Obstet Gynecol 2012: 375806, 2012.

42. Yang Q, Zhao WF and Zheng JP: Clinical observat ion of mycobacterium lacticola preparation in treatment of vaginal vini candidiasis using clotrimazole effervescent tablets. Chin Hosp Pharm J 29: 1377-1379, 2009.

43. Martinez RC, Franceschini SA, Patta MC, Quintana SM, Candido RC, Ferreira JC, De Martinis EC and Reid G: Improved treatment of vulvovaginal candidiasis with fluconazole plus probiotic Lactobacillus rhamnosus GR $\square 1$ and Lactobacillus reuteri RC口14. Lett Appl Microbiol 48: 269ロ274, 2009.

44. Ehrstrom S, Daroczy K, Rylander E, Samuelsson C, Johannesson U, Anzèn B and Påhlson C: Lactic acid bacteria colonization and clinical outcome after probiotic supplementation in conventionally treated bacterial vaginosis and vulvovaginal candidiasis. Microbes Infect 12: 691-699, 2010.

45. Ya W, Reifer C and Miller LE: Efficacy of vaginal probiotic capsules for recurrent bacterial vaginosis: A double-blind, randomized, placebo-controlled study. Am J Obstet Gynecol 203: 120.e1-e6, 2010.

46. Falagas ME, Betsi GI and Athanasiou S: Probiotics for prevention of recurrent vulvovaginal candidiasis: A review. J Antimicrob Chemother 58: 266-272, 2006.

This work is licensed under a Creative Commons Attribution-NonCommercial-NoDerivatives 4.0 International (CC BY-NC-ND 4.0) License. 